ks. Wojciech Zyzak ${ }^{1}$

Uniwersytet Papieski Jana Pawła II w Krakowie

\title{
Edyta Stein - Teresa Benedykta od Krzyża w życiu i pismach Karola Wojtyły - Jana Pawła II
}

Maciej Zięba OP w książce będącej kompendium twórczości i nauczania Karola Wojtyły - Jana Pawła II zaliczył homilię beatyfikacyjną Edyty Stein z 1 maja 1987 roku do nielicznej grupy przemówień, które zmieniły świat. Pisząc o głębokiej więzi polskiego papieża z karmelitanką, autor stwierdził: „Ta pochodząca z Wrocławia niemiecka Żydówka to postać niezwykle bliska duchowo Janowi Pawłowi II (w teologii - z racji umiłowania karmelitańskiej duchowości, w filozofii - z racji posługiwania się metodą fenomenologii). Papież jedenaście lat później kanonizował Edith Stein, a w następnym roku ogłosił patronką Europy. W ten sposób Jan Paweł II przybliżył całemu światu postać wybitnej intelektualistki,

1 Ks. prof. dr hab. Wojciech Zyzak, ur. 1969 w Żywcu. Od 1993 kapłan diecezji bielsko-żywieckiej. Od 2014 rektor Uniwersytetu Papieskiego Jana Pawła II w Krakowie. Zainteresowania naukowe: duchowość laikatu, duchowość kapłańska, mistyka karmelitańska, duchowość zmartwychwstańców. Najważniejsze publikacje: Zjednoczenie z Bogiem w życiu Ojca Pio (Francesco Forgione). Studium na podstawie jego pism, Kraków 2000; Fundamentalna rola wiary w życiu i pismach świętej Teresy Benedykty od Krzyża (Edyty Stein), Kraków 2005; Co mam czynić, aby osiagnać życie wieczne? Duchowość chrześcijańska na świeckiej drodze życia, Kraków 2008; Kapłaństwo prezbiterów. Studium nauczania Jana Pawła II, Kraków 2010. E-mail: wojciech. zyzak@upjp2.edu.pl. 
świętej karmelitanki i żydówki zamordowanej w Auschwitz"2. W tej krótkiej charakterystyce zawarte zostały najważniejsze elementy więzi obojga świętych, które w poniższym tekście zostaną rozwinięte w oparciu o wątki biograficzne, podobieństwo intelektualne i duchowe oraz wypowiedzi Karola Wojtyły - Jana Pawła II na temat Edyty Stein jako męczennicy, filozofa, błogosławionej, a następnie świętej kobiety i współpatronki Europy.

\section{Wątki biograficzne}

Refleksja na temat związku Edyty Stein i Karola Wojtyły na pierwszy plan wysuwa pewne podobieństwo biograficzne. Oczywiście święci raczej nigdy się nie spotkali, choć teoretycznie mogli. Jednak w ich życiorysach jest wiele zbieżności. Edyta utraciła ojca, gdy miała dwa lata, Karol utracił matę $\mathrm{w}$ wieku sześciu lat. $\mathrm{Z}$ tym wiąże się zapewne wielki wpływ wspaniałych i oddanych dzieciom rodziców: matki na Edytę, a ojca na Karola. Edyta początkowo studiowała ojczystą filologię niemiecką, podobnie Karol, który zaczynał studia od filologii polskiej. W późniejszym okresie rozpoczynają studia filozoficzne. Edyta w Getyndze studiuje filozofię u Husserla. Wśród jego uczniów jest Max Scheler, którego myśl będzie później stanowić temat habilitacji Wojtyły. Uderzający jest związek obu postaci z duchowością karmelitańską. Edyta Stein przyjęła katolicyzm i wstąpiła do Karmelu pod wpływem Teresy Wielkiej. Nauczyła się języka hiszpańskiego, by studiować Jana od Krzyża, któremu poświęciła swe ostatnie dzieło. Również Karol był pod wpływem karmelitów z Wadowic. Cenił Teresą Wielką, również dzięki Janowi Tyranowskiemu, a Janowi od Krzyża poświęcił swój doktorat.

Niektórzy dopatrują się pewnej analogii odkrycia Bożego powołania w życiu obojga świętych w przezwyciężeniu sytuacji kryzysowej. Takim momentem dla Karola Wojtyły była śmierć ojca w 1942 roku, gdy pozostał sam, bez rodziców i rodzeństwa. We wrześniu tego roku poprosił

2 M. Zięba OP, Jestem z wami. Kompendium twórczości i nauczania Karola Wojtyły - Jana Pawła II, Kraków 2010, s. 248. 
o przyjęcie do seminarium. W wypadku Edyty Stein mamy całe pasmo wewnętrznych kryzysów, które poprzedzają przyjęcie wiary. Trzeba jednak pamiętać, że w jej życiu moment przyjęcia chrześcijaństwa był też momentem powołania zakonnego. Do jego realizacji doszło po utracie pracy ze względu na żydowskie pochodzenie. Wspomniany wcześniej 1942 rok jest rokiem męczeńskiej śmierci Edyty Stein. W momencie, w którym Karol Wojtyła przeżywał swoją noc duchową, w odległości kilkudziesięciu kilometrów w obozie była kobieta, która oddała życie za Chrystusa, modląc się za obecnych tam ludzi oraz za Kościół

Pewne znaczenie może mieć też metamorfoza, jaka nastąpiła w życiu obojga świętych wraz z przyjęciem nowego imienia w Kościele. $\mathrm{W}$ tradycji chrześcijańskiej jest to związane z przyjęciem nowej misji i w pewnym sensie nowego wymiaru osobowości. Dostrzegamy potężne działanie Bożej łaski w momencie, gdy Edyta Stein stała się Teresą Benedyktą od Krzyża i gdy Karol Wojtyła przyjął imię Jan Paweł II. Anna Grzegorczyk widzi tu wpływ misterium Krzyża. Jej zdaniem Edyta Stein w misteryjnym przeobrażeniu przechodzi w Benedyktę od Krzyża, zaś Karol Wojtyła w Jana Pawła II ${ }^{4}$.

\section{Wspólnota myślenia}

Wspomniane wyżej podobieństwa biograficzne idą w parze ze wspólnym dla obojga świętych zainteresowaniem filozofią. Jak przypomina Andrzej Półtawski, na początku XIX i XX wieku zapoczątkowany został ruch fenomenologiczny, za którego inicjatora uchodzi Edmund Husserl. Przyjął on podstawowe założenia kartezjanizmu, otrzymał jednak znaczące inspiracje od scholastyki, poprzez swego nauczyciela Franciszka Brentana. Zagadnieniami etyki i religii zajmował się w ramach ruchu fenomenologicznego przede wszystkim Max Scheler. On to zwrócił uwagę

\footnotetext{
3 Por. R. Skrzypczak, Edyta Stein jest perła, ,Gość Niedzielny” 32 (2017), http://gosc.pl/ doc/4093306.Edyta-Stein-jest-perla (10.08.2017); A. Półtawski, Realizm fenomenologii. HusserlIngarden-Stein-Wojtyła, Torun 2000, s. 285.

4 Por. A. Grzegorczyk, Poznanie metaracjonalne Edyty Stein i Karola Wojtyły, „Kwartalnik Filozoficzny" 4 (2005), s. 74.
} 
Edyty Stein na powagę problematyki religijnej. Jego poglądy etyczne były też tematem pracy habilitacyjnej Karola Wojtyły ${ }^{5}$. Te formalne zależności wpływają na pewną bliskość myślenia. Filozofie Edyty Stein i Karola Wojtyły określamy jako personalistyczne. Można je też uznać za fenomenologiczne. Podczas gdy tradycyjna filozofia arystotelesowsko-tomistyczna nastawiona była raczej na ogólną metafizykę, fenomenologowie wychodzili od analizy świadomości. Toteż Karol Wojtyła kładł nacisk na nieredukowalną do kosmosu strukturę człowieka, na jego bycie osobą. Podejście personalistyczne przeciwstawiał traktowaniu człowieka jedynie jako części kosmosu. Dla podejścia kosmologicznego to, co nieredukowalne w człowieku, pozostaje pustym miejscem, które może zostać wypełnione dopiero przez badanie zorientowane personalistycznie. Przeżyciem, w którym prezentuje się nam to, co specyficznie ludzkie, nie jest dla Karola Wojtyły, jak dla Husserla, poznawczy akt świadomości, ale przeżycie etyczne. Świadome, wolne, podlegające ocenie moralnej działanie dojrzałej osoby ludzkiej, jej czyn, może nam pozwolić na wglądnięcie w jej rzeczywistość. Owocem wolnych czynów człowieka jest moralność. Przez czyn moralnie dobry lub zły sam człowiek jako osoba staje się moralnie dobry lub zły. Wiąże się z tym kwestia sumienia i wartości ${ }^{6}$.

Specjaliści są zgodni co do tego, że wspólne źródła myśli filozoficznej Edyty Stein i Karola Wojtyły to tomizm i fenomenologia. Przyznanie pierwszeństwa w oświetlaniu sensu świata doświadczeniu innych ludzi wyznacza nurt personalistyczny w fenomenologii. Jego prekursorką dzięki metodzie wczucia jest Edyta Stein. U Karola Wojtyły mamy rozważania nad prawdą i strukturą osoby. Dobro osoby to istnienie w Prawdzie i czynie. Prawda Absolutu oświeca rozum i kształtuje wolność człowieka. Ta koncepcja prawdy jednoczy aspekty ontologiczno-epistemologiczne oraz podkreśla związek prawdy z miłością ${ }^{7}$. Z punktu widzenia metodologii fenomenologicznej postępowanie Wojtyły spotyka się z podobną krytyką, jaką wobec Edyty Stein wysuwał Roman Ingarden. Marek

5 Por. A. Półtawski, Realizm fenomenologii. Husserl-Ingarden-Stein-Wojtyła, Toruń 2000, s. $284 \mathrm{n}$.

6 Por. A. Półtawski, Realizm fenomenologii..., dz. cyt., s. 285n.

7 Por. A. Grzegorczyk, Poznanie metaracjonalne Edyty Stein i Karola Wojtyły, „Kwartalnik Filozoficzny" 4 (2005), s. 64n. 
Olejniczak pisze, że odnośnie do podjętej przez Wojtyłę próby godzenia ze sobą tomizmu z fenomenologią należy stwierdzić, że nie jest to próba udana, ponieważ nie spełnia ona podstawowego dla fenomenologii kryterium bezzałożeniowości. Wojtyła otwarcie wyznaje, że z góry przyjmuje Tomaszową koncepcję osoby ludzkiej oraz czynu, a metoda fenomenologiczna ma pomóc jedynie w eksplikacji założeń w niej zawartych. Odwoływanie się Wojtyły do doświadczenia fenomenologicznego ma charakter jedynie służebny wobec metafizyki. Wątpliwa jest jednak teza autora, że w filozofii Stein sytuacja jest odmienna, gdyż wątki metafizyczny i fenomenologiczny prowadzone są przez nią niejako równolegle, żaden z nich nie jest ważniejszy od drugiego, i na tej podstawie próbuje ona łączyć te filozofie ${ }^{8}$.

W każdym razie, pomijając aspekty metodologiczne, trzeba przyznać, że zainteresowanie osobą ludzką łączy filozofie obojga świętych. Zauważenie fenomenu „człowiek działa” i przyjęcie czynu jako szczególnego momentu wglądu w osobę umożliwia Wojtyle przekroczenie progu czystego subiektywizmu fenomenologii Husserla. To przekroczenie dzieli wraz z Edytą Stein, która dochodzi do niego dzięki wczuciu? . Nie ulega wątpliwości ukierunkowanie człowieka na drugą osobę w personalizmie fenomenologicznym Edyty Stein, a także poszukiwanie istoty osoby w jej dialogiczności. Dokonuje się to za sprawą Einfühlung, będącego poznaniem ,[...] drugiego człowieka jako istoty świadomej w dialogicznym stosunku do drugiego"10. Stąd Andrzej Półtawski może podkreślić zgodność treści personalizmu Edyty Stein i Karola Wojtyły. Jego zdaniem różnią się akcentami. Hasłem filozofii Wojtyły jest wolny, odpowiedzialny c zy n rozwijającej się moralnie osoby ludzkiej, dla antropologii Stein jest to ży ci e. Wojtyła analizował w pracach przede wszystkim struktury wolnego, odpowiedzialnego działania, zaś uwaga Edyty skierowana jest na wewnętrzne życie duszy, zwłaszcza na życie łaski od Boga ${ }^{11}$. W obrębie

8 Por. M. Olejniczak, Wolność miłości. Ontologia osoby ludzkiej w koncepcjach Edyty Stein i Karola Wojtyły, Tarnów 2010, s. 254.

9 Por. A. Grzegorczyk, Poznanie metaracjonalne Edyty Stein i Karola Wojtyły, dz. cyt., s. 67.

10 A. Grzegorczyk, Poznanie metaracjonalne Edyty Stein i Karola Wojtyły, dz. cyt., s. 67.

11 Por. A. Półtawski, Realizm fenomenologii..., dz. cyt., s. 291; A. Półtawski, Personalizm fenomenologiczny: Edith Stein i Karol Wojtyła, „Kwartalnik Filozoficzny” 1 (1995), s. 44n. Z tą 
struktury ontycznej człowieka obecny jest rozumny $i$ wolny duch, zdolny zarówno do transcendowania naturalnych uwarunkowań psychosomatycznych, jak i do miłości rozumianej jako dar z samego siebie. To jest wspólne ontologii Stein i Wojtyły ${ }^{12}$.

Anna Grzegorczyk w oparciu o obie koncepcje postuluje uzupełnienie filozofii przez mistykę. Mistyka, obnażając fundamenty filozofii i religii, jednoznacznie przywraca do łask doświadczenie wewnętrzne jako niezbywalny element budowania tożsamości człowieka. To poszerzenie granic poznania jako filozoficzny protest przeciw samoograniczeniu się rozumu wpisze się w historyczny kontekst filozofii Edyty Stein i Karola Wojtyły ${ }^{13}$. Edyta, wychodząc z neutralnych światopoglądowo pozycji fenomenologii, rozszerza ją w kierunku filozofii światła. Karol Wojtyła rozpoczyna od „świetlistej religii” św. Jan od Krzyża i wmontowuje ją $\mathrm{w}$ fenomenologię ${ }^{14}$. Edyta Stein wieńczy drogę filozoficzno-egzystencjalną refleksją o św. Janie od Krzyża, podczas gdy Karol Wojtyła od niej zaczyna ${ }^{15}$. Edyta Stein poświęcała wiele uwagi , państwu” czy porządkowi łaski, zaś Karol Wojtyła w swej pracy doktorskiej o św. Janie od Krzyża analizuje rolę wiary w tym „państwie”"16.

Wprawdzie Anna Grzegorczyk, pisząc o wpływie Edyty Stein na filozofię XXI wieku, nie wspomina o Karolu Wojtyle - Janie Pawle II ${ }^{17}$, jednak zarówno ona, jak i inni badacze filozofii podkreślają wiele elementów wspólnych myśli Stein i Wojtyły. „Poznanie kryształowe, jako odmiana poznania metaracjonalnego, łączące rozum i wiarę, rozum z Prawdą Najwyższą - Słowem i Symbolem, Światłem i Logosem, uskuteczniło się w pełnym wymiarze w życiu i refleksji E. Stein i K. Wojtyły" ${ }^{18}$. W koncepcji

tezą polemizuje A. Grzegorczyk, Poznanie metaracjonalne Edyty Stein i Karola Wojtyły, dz. cyt., s. 70 .

12 Por. M. Olejniczak, Wolność miłości. Ontologia osoby ludzkiej w koncepcjach Edyty Stein i Karola Wojtyły, Tarnów 2010, s. 255.

13 Por. A. Grzegorczyk, Poznanie metaracjonalne Edyty Stein i Karola Wojtyły, dz. cyt., s. 63.

14 Por. A. Grzegorczyk, Poznanie metaracjonalne Edyty Stein i Karola Wojtyły, dz. cyt., s. 69.

15 Por. A. Grzegorczyk, Poznanie metaracjonalne Edyty Stein i Karola Wojtyły, dz. cyt., s. 74.

16 Por. A. Półtawski, Realizm fenomenologii..., dz. cyt., s. 290.

17 Por. A. Grzegorczyk, Wpływ myśli Edyty Stein na filozofię XXI wieku, w: Bóg i Auschwitz, red. M. Deselaers, Kraków 2007, s. 35-48.

18 Por. A. Grzegorczyk, Poznanie metaracjonalne Edyty Stein i Karola Wojtyły, dz. cyt., s. 88. 
Wojtyły dochodzi się do teorii, w której ogląd intelektualny łączy się z poznaniem praktycznym, ze zrozumieniem działania i życia świadomego. Uteoretyczniona praxis pozwala na wniknięcie w rzeczywistość realnie istniejącą. Poznanie osoby przez czyn jest złączeniem aspektu bytowo-podmiotowego, ontologiczno-epistemologicznego; złączeniem filozofii bytu i świadomości. Jednak, co najważniejsze, personalizm obojga filozofów odrzuca relatywizację prawdy i pozwala zadać najbardziej fundamentalne pytania o człowieka ${ }^{19}$.

\section{Karol Wojtyła o Edycie Stein}

Ukazana wyżej wspólnota myśli Edyty Stein i Karola Wojtyły przyczyniła się zapewne do tego, że święty już jako biskup krakowski interesował się postacią męczennicy z Birkenau. Najpierw wspominał ją wraz z Maksymilianem Kolbem. Już w 1964 roku pisał: „W obozie oświęcimskim zginął w opinii świętości polski franciszkanin O. Maksymilian Kolbe, podobnie zresztą jak Siostra Teresa Benedykta od Krzyża, karmelitanka niemiecka, skierowana wprost z transportu do likwidacji. $\mathrm{W}$ toku są ich procesy beatyfikacyjne" ${ }^{20}$. W następnym roku, mówiąc w radiu watykańskim o dwudziestej rocznicy oswobodzenia obozu oświęcimskiego, zaznaczył: „Przecież byli ludzie, którzy właśnie w Oświęcimiu osiągnęli pełnię człowieczeństwa i zdobyli swe ostateczne podobieństwo do Chrystusa. Wspomnijmy chociażby O. Maksymiliana Kolbe czy też Edytę Stein" ${ }^{21}$.

Najbardziej wymowne w tym względzie jest przemówienie kardynała Wojtyły w Monachium, na kilka tygodni przed wyborem na Stolice Piotrową. Późniejszy papież mówił o poparciu episkopatu Niemiec dla beatyfikacji Maksymiliana i episkopatu Polski dla beatyfikacji Edyty

19 Por. A. Grzegorczyk, Poznanie metaracjonalne Edyty Stein i Karola Wojtyły, dz. cyt., s. 68.

20 K. Wojtyła, Odezwa ks. Metropolity $w$ XX rocznicę wyzwolenia obozu oświęcimskiego (27 I 1945 - 27 I 1964), „Notificationes e Curia Metropolitana Cracoviensi” 5 (1965), s. 112.

21 K. Wojtyła, Przemówienie w Radio Watykańskim 18 II 1965 r. w zwiazku z 20-leciem oswobodzenia obozu oświęcimskiego, w: Karol Wojtyła - Jan Paweł II, Patron naszych trudnych czasów, wybór i red. R. Deyna, Niepokalanów 1991, s. 13. 
Stein. Wspomniał o karmelitankach bosych modlących się na terenie obozu, dzięki poparciu kardynała Juliusza Döpfnera: „Dlaczego właśnie Karmelitanki? Mogą być różne do tego powody. Jednakże szczególnym powodem zdaje się być służebnica Boża s. Benedykta od Krzyża - w świecie Edyta Stein - uczennica i asystentka znakomitego Husserla, a potem również karmelitanka bosa, a potem ofiara krematorium Oświęcimia, tak jak O. Maksymilian, ofiara bunkra, w którym ginęło się śmiercią głodową. Jeśli kiedyś Kościół wyniesie na ołtarze s. Benedyktę od Krzyża, o co stara się Episkopat Niemiecki przy poparciu także polskich biskupów, oboje Maksymilian Kolbe i Edyta Stein - będą wołali do nas Polaków i Niemców z tego samego miejsca męczeńskiej śmierci, którą ponieśli, nie wiedząc wzajemnie o sobie: «Tylko sprawujcie się w sposób godny Ewangelii». Wymowa tego wezwania będzie wówczas jeszcze potężniejsza"22. Trzeba jednak dodać, że jeszcze przed wyborem na papieża Karol Wojtyła interesował się Edytą Stein także ze względu na jej dorobek naukowy. Świadczy o tym wzmianka w kalendarium życia Karola Wojtyły zawierająca informację: „6 kwietnia 1968: o 11.00 w rezydencji sesja naukowa ku czci Edyty Stein $\mathrm{z}$ referatem prof. R. Ingardena" ${ }^{23}$.

\section{Edyta Stein jako filozof}

Już powyższe refleksje wytyczają krąg tematów, które w kontekście Edyty Stein poruszał Jan Paweł II. Podczas pielgrzymki do Polski w 1979 roku w Brzezince święty papież wspomniał zarówno męczeństwo Maksymiliana Kolbego, jak i śmierć w piecu krematorium obozu Birkenau Edyty Stein, jak mówił, wspaniałej uczennicy Husserla, która stała się ozdobą współczesnej niemieckiej filozofii ${ }^{24}$. Nic dziwnego, że jej

22 K. Wojtyła, Homilia ks. Kard. Karola Wojtyły wygłoszona 24 IX 1978r. w katedrze w Monachium (Bawaria) na zakończenie wizyty delegacji Episkopatu polskiego w RFN, w: Karol Wojtyła - Jan Paweł II, Patron naszych trudnych czasów, dz. cyt., s. 143.

23 Kalendarium życia Karola Wojtyły, red. A. Boniecki, Kraków 2000, s. 253n.

24 Por. Giovanni Paolo II, Al campo di concentramento di Brzezinka, 07.06.1979, w: Insegnamenti 1979 II, Vaticano 1988, s. 1483. 
wstawiennictwu powierzył opublikowaną niedługo po kanonizacji karmelitanki encyklikę Fides et ratio ${ }^{25}$.

W samej encyklice święty poświęcił uwagę osiągnięciom naukowym Teresy Benedykty od Krzyża. Najpierw podkreślił pewien sposób refleksji, w który wpisuje się dorobek świętej karmelitanki: „Odnowa tomistyczna i neotomistyczna nie była jednak jedynym przejawem odrodzenia się myśli filozoficznej w kulturze o inspiracji chrześcijańskiej. Już wcześniej i niezależnie od wezwania rzuconego przez papieża Leona pojawili się liczni teolodzy katoliccy, którzy nawiązując do nowszych nurtów myślowych i posługując się własną metodologią, stworzyli dzieła filozoficzne o wielkiej sile oddziaływania i trwałej wartości. Niektórzy z nich wypracowali niezwykle ambitne syntezy, w niczym nieustępujące wielkim systemom idealistycznym; inni położyli podwaliny epistemologiczne pod nowy opis wiary w świetle odnowionej koncepcji sumienia; inni znów stworzyli filozofię, która wychodząc od analizy rzeczywistości immanentnej, otwierała drogę ku transcendencji; inni wreszcie podjęli próbę pogodzenia wymogów wiary z zasadami metodologii fenomenologicznej" ${ }^{26}$.

Warto zacytować szerszy fragment tego dokumentu, w którym papież wyraźnie wymienia osiągnięcia Edyty Stein: „Jak wynika z tych rozważań, pożądaną więź między teologią a filozofią należy rozpatrywać w dwukierunkowym odniesieniu: punktem wyjścia i pierwotnym źródłem dla teologii musi być zawsze słowo Boże objawione w dziejach, a ostatecznym celem nic innego jak zrozumienie tegoż słowa, stopniowo pogłębiane przez kolejne pokolenia. Z drugiej strony, skoro słowo Boże jest Prawdą (por. J 17, 17), to do lepszego zrozumienia go przyczynia się z pewnością ludzkie poszukiwanie prawdy, czyli refleksja filozoficzna, prowadzona zgodnie z właściwymi jej zasadami. [...] Dzięki takiej relacji ze słowem Bożym, które jest punktem wyjścia i celem, filozofia zostaje wzbogacona, ponieważ rozum odkrywa nowe i nieoczekiwane horyzonty. Potwierdzeniem owocności tego rodzaju więzi jest osobiste

25 Por. Giovanni Paolo II, Angelus Domini, 18. 10.1998, w: Insegnamenti 1998 XXI/2, Vaticano 2000, s. 768.

26 Giovanni Paolo II, Lettera enciclica Fides et ratio, 59, 14.09.1998, w: Insegnamenti 1998 XXI/2, Vaticano 2000, s. 332. 
doświadczenie wielkich chrześcijańskich teologów, którzy wyróżnili się także jako wybitni filozofowie, pozostawili bowiem pisma spekulatywne tak wielkiej wartości, że wolno ich porównywać do mistrzów filozofii starożytnej. [...] Przejawem owocnej relacji między filozofią a słowem Bożym są też śmiałe poszukiwania podjęte przez myślicieli bliższych nam w czasie, spośród których chciałbym wymienić takie postaci, jak John Henry Newman, Antonio Rosmini, Jacques Maritain, Étienne Gilson i Edyta Stein w świecie zachodnim, a w kręgu kultury wschodniej uczonych formatu Władimira S. Sołowjowa, Pawła A. Florenskiego, Piotra J. Czaadajewa, Władimira N. Łosskiego. Oczywiście powołując się na tych autorów, obok których można by wymienić jeszcze innych, nie zamierzam bynajmniej wyrazić aprobaty dla całokształtu ich poglądów, ale jedynie wskazać ich jako znamienne przykłady pewnego typu refleksji filozoficznej, która wiele zyskała dzięki konfrontacji z prawdami wiary. Jedno jest pewne: zapoznanie się z drogą duchowego rozwoju tych myślicieli przyczyni się do postępu w poszukiwaniu prawdy i pozwoli lepiej wykorzystać osiaggnięte rezultaty w służbie człowiekowi. Wypada sobie życzyć, aby ta wielka tradycja filozoficzno-teologiczna znalazła dzisiaj i w przyszłości kontynuatorów i badaczy dla dobra Kościoła i ludzkości”27.

\section{Refleksje na kanwie beatyfikacji}

Kolejny istotny moment zainteresowania Edytą Stein związany był zjej beatyfikacją w czasie pielgrzymki do Niemieckiej Republiki Federalnej. Papież prosił chorych o modlitwę $\mathrm{w}$ tej intencji ${ }^{28}$. Wszystkie wystąpienia poprzedzające beatyfikację skupiały uwagę wiernych na męczeńskiej śmierci Teresy Benedykty od Krzyża. W przesłaniu telewizyjnym do Niemców przed swą drugą pielgrzymką papież powiedział o niej: „Wierzyła w Jezusa, w Jezusa jako Mesjasza, Zbawiciela, Odkupiciela świata. W nim szukała i znalazła ostateczny sens swego życia. Rozumiała

27 Giovanni Paolo II, Lettera enciclica Fides et ratio, 73n, dz. cyt., s. 344n.

28 Por. Giovanni Paolo II, Udienza generale, 29.04.1987, w: Insegnamenti 1987 X/1, Vaticano 1988, s. 1464 . 
swoje życie i umieranie jako uczestnictwo w krzyżu Jezusa”. Następnie papież przypomniał, że jak Jezus oddała się bezgranicznie niebieskiemu Ojcu i zaufała Jego miłości. Została zabita jako katolicka Żydówka w obozie koncentracyjnym Auschwitz-Birkenau. Święty zacytował też jej słowa: „Nienawiść nie może mieć w świecie ostatniego słowa” ${ }^{29}$. W chwili przybycia do Niemiec na lotnisku Jan Paweł II przypomniał, że Edyta Stein w solidarności z jej umęczonym żydowskim narodem jako Żydówka i katolicka zakonnica przeszła z nadzieją chrześcijańską drogę cierpienia jej narodu aż do zagłady ${ }^{30}$. Do biskupów niemieckich mówił o kontekście historycznym, przejęciu władzy przez Hitlera a także odważnych kazaniach pasterzy Kościoła, głównie liście protestacyjnym holenderskiego episkopatu oraz liście Piusa XI z 1937 roku Mit brennender Sorge. Na tym tle ukazał Edytę Stein jako kobietę głębokiej modlitwy, szczególnie od momentu uwięzienia na drodze cierpienia w Shoah ${ }^{31}$. Podobnie w przemówieniu do Komitetu Niemieckich Katolików papież skupił się na drodze męczennicy do Auschwitz jako wstawianiu się za narodem żydowskim, z którym do śmierci czuła się związana. W tym kontekście przytoczył jej słowa do siostry Róży: „chodź idziemy za nasz naród”32.

Niezwykle istotna, poszerzająca dotychczasowy obraz Edyty Stein w nauczaniu Jana Pawła II jest homilia wygłoszona w czasie liturgii beatyfikacyjnej Edyty Stein, którą papież ukazał jako żydówkę, filozofa, zakonnicę i męczennicę. Ojciec święty odniósł się do starotestamentowej postaci Estery, bardzo bliskiej błogosławionej, która stała się ofiarą nienawiści nazistów wobec Żydów, mimo prób obrony ze strony biskupów holenderskich. Papież, przedstawiając zwięźle jej całą biografię, ukazał ją jako kobietę stale szukającą prawdy, która po wewnętrznym kryzysie, dzięki fenomenologii, wdowie po Reinachu, Schelerowi i lekturze

29 Giovanni Paolo II, Messaggio televisivo al Popolo Tedesco, 25.04.1987, w: Insegnamenti 1987 X/1, Vaticano 1988, s. 1420.

30 Por. Giovanni Paolo II, All'arrivo all'aeroporto di Köln-Bonn, 30.04.1987, w: Insegnamenti 1987 X/1, Vaticano 1988, s. 1469.

31 Por. Giovanni Paolo II, Il discorso ai membri della Conferenza Episcopale Tedesca, 30.04.1987, w: Insegnamenti 1987 X/1, Vaticano 1988, s. 1472-1478.

32 Giovanni Paolo II, Al comitato centrale die cattolici tedeschi, 30.04.1987, w: Insegnamenti 1987 X/1, Vaticano 1988, s. 1482. 
Księgi życia Teresy Wielkiej znalazła ją w Chrystusie ukrzyżowanym. Stanowiło to okazję do ukazania znaczenia krzyża w życiu błogosławionej. Edyta, od chwili chrztu działając w świecie nauki, przygotowywała się do Karmelu i do zgłębienia cierpienia w wiedzy krzyża, aż po męczeństwo $^{33}$. Do powyższych wątków papież powracał również podczas dalszych spotkań w Republice Federalnej Niemiec. Na spotkaniu z przedstawicielami Żydów ukazał błogosławioną jako ofiarę nazistowskich prześladowań ${ }^{34}$, w Münster podkreślił początki jej drogi do Karmelu ${ }^{35}$, zaś w Spirze, zwracając uwagę na rozwój jej życia duchowego, postawił ją za wzór współczesnym kobietom ${ }^{36}$. Również w późniejszym czasie Jan Paweł II nawiązywał do postaci błogosławionej, ukazując ją jako pełną heroicznych cnót męczennicę ${ }^{37}$, wzór życia konsekrowanego płynącego z Eucharystii ${ }^{38}$ i w pełni miłości Serca Jezusowego oddanego bliźnim, zwłaszcza cierpiącym ${ }^{39}$. Do momentu kanonizacji w 1998 roku Jan Paweł II ukazywał Teresę Benedyktę od Krzyża pośród karmelitanek bosych, które z miłością medytując pisma św. Jana od Krzyża, doszły do szczytów życia wewnętrznego ${ }^{40}$. Syntetycznie mówił o niej podczas

33 Por. Giovanni Paolo II, Omelia durante la solenne concelebrazione nello stadio di KölnMüngersdorf, 01.05.1987, w: Insegnamenti 1987 X/2, Vaticano 1988, s. 1485-1493.

34 Por. Giovanni Paolo II, Ai membri del Consiglio Centrale degli Ebrei incontrati nella residenza dell'arcivescovo di Colonia, 01.05.1987, w: Insegnamenti 1987 X/2, Vaticano 1988, s. 1497n.

35 Por. Giovanni Paolo II, Münster: Incontro con la popolazione nella Schlossplatz, 01.05.1987, w: Insegnamenti 1987 X/2, Vaticano 1988, s. 1501.

36 Por. Giovanni Paolo II, Speyer: L'omelia durante la concelebrazione davanti alla cattedrale, 04.05.1987, w: Insegnamenti 1987 X/2, Vaticano 1988, s. 1601.

37 Por. Giovanni Paolo II, Udienza generale, 06.05.1987, w: Insegnamenti 1987 X/2, Vaticano 1988, s. 1613.

38 Por. Giovanni Paolo II, Varsavia: L'incontro con le suore di clausura nella cattedrale di San Giovanni Battista, 08.06.1987, w: Insegnamenti 1987 X/2, Vaticano 1988, s. 2034.

39 Por. Giovanni Paolo II, All'unione superiore maggiori d'Italia, 09.04.1988, w: Insegnamenti 1988 X/1, Vaticano 1988, s. 840.

40 Por. Giovanni Paolo II, Lettera apostolica nel IV centenario della morte di S. Giovanni della Croce „Maestro en la Fe”, 20, 14.12.1990, w: Insegnamenti 1990 XIII/2, Vaticano 1992, s. 1638; Giovanni Paolo II, Lettera alle carmelitane scalze in occasione dell'approvazione dei loro codici fondamentali, 01.10.1991, w: Insegnamenti 1991 XIV/2, Vaticano 1993, s. 704. 
rozważań na Anioł Pański 1995 roku jako o kobiecie, której życie, nawrócenie, miłość bliźniego i męczeństwo służą sprawie pokoju ${ }^{41}$.

\section{6. Święta Teresa Benedykta od Krzyża}

W kazaniu z okazji kanonizacji Edyty Stein Jan Paweł II, stawiając ją obok Teresy z Ávili i Teresy z Lisieux, podkreślił jej umiłowanie krzyża Chrystusowego. Zacytował jej wypowiedź wyrażającą gotowość na męczeństwo w jedności z narodem żydowskim i odmawiającą przywileju ratunku: „Nie róbcie tego: dlaczego miałabym być wyłączona? Czy sprawiedliwość nie polega właśnie na tym, abym nie czerpała korzyści z faktu mojego chrztu? Jeśli nie wolno mi podzielić losu moich braci i sióstr, moje życie byłoby - w pewnym sensie - zniszczone". Papież wspomniał duchową drogę Edyty Stein do odnalezienia prawdy i wolności w Chrystusie, wyrażoną słowami: „Kto szuka prawdy, świadomie lub nieświadomie szuka Boga”, oraz: „Tylko kto wiąże się z miłością Chrystusa, staje się rzeczywiście wolny”. W tym kontekście związku prawdy z miłością padły znamienne słowa: „Nie przyjmujcie niczego za prawdę, co byłoby pozbawione miłości, ani nie przyjmujcie niczego jako miłość, co byłoby pozbawione prawdy; jedno pozbawione drugiego staje się niszczącym kłamstwem”. Jan Paweł II ukazał świętą także jako przykład zrozumienia związku cierpienia z miłością w perspektywie krzyża ${ }^{42}$.

Również w późniejszych wystąpieniach Jan Paweł II nawiązywał do św. Teresy Benedykty od Krzyża, czasami wskazując na nowe wątki jej duchowości. Tak było, gdy mówił o identyfikacji świętej z Matką Bożą, cytując jej słowa: „Stać na modlitwie przed Bogiem, miłować Go całym sercem, błagać o Jego łaskę dla grzesznego ludu, ofiarując się za niego i jako służebnica Pańska być uważną na każde Jego skinienie: takie było jej życie”. Zdaniem papieża Edyta Stein, także jako córka narodu

${ }^{41}$ Por. Giovanni Paolo II, Angelus Domini, 26.02.1995, w: Insegnamenti 1995 XVIII/1, Vaticano 1997, s. 433n.

42 Por. Giovanni Paolo II, L'omelia durante il rito di santificazione di Teresa Benedetta della Croce (Edith Stein), 11.10.1998, w: Insegnamenti 1998 XXI/2, Vaticano 2000, s. 713-718. 
żydowskiego, mówiła o Maryi i prawie nie zauważając, znaczyła program swego życiowego wyboru ${ }^{43}$. Od momentu kanonizacji Jan Paweł II mówił o Edycie Stein jako przykładzie dla młodych na to, że autentyczna miłość nie może być odłączona od prawdy, dla chorych - że krzyż Chrystusa jest tajemnicą miłości, która zbawia ludzkie cierpienie, dla małżonków że należy być wiernym Bogu, który każdemu powierza specjalną misję ${ }^{44}$. Powyższe wątki występują również w innych, krótkich wystąpieniach, wspominających życie, męczeńską śmierć, beatyfikację i kanonizację świętej ${ }^{45}$.

43 Por. Giovanni Paolo II, Angelus Domini, 11.10.1998, w: Insegnamenti 1998 XXI/2, Vaticano 2000, s. 719-721.

44 Por. Giovanni Paolo II, Udienza generale, 14.10.1998, w: Insegnamenti 1998 XXI/2, Vaticano 2000, s. 736; Giovanni Paolo II, Udienza generale, 09.08.2000, w: Insegnamenti 2000 XXIII/2, Vaticano 2002, s. 143.

45 Por. Giovanni Paolo II, L'omelia durante la concelebrazione al Parkstadion di Gelsenkirchen, 02.05.1987, w: Insegnamenti 1987 X/2, Vaticano 1988, s. 1544; Giovanni Paolo II, München: L'omelia durante la concelebrazione nell' Olympiastadion, 03.05.1987, w: Insegnamenti 1987 X/2, Vaticano 1988, s. 1555; Giovanni Paolo II, Augsburg: L'omelia durante la Santa Messa nella cattedrale, 03.05.1987, w: Insegnamenti 1987 X/2, Vaticano 1988, s. 1569; Giovanni Paolo II, La consegna ai fedeli della Germania Federale a Spira, 04.05.1987, w: Insegnamenti 1987 X/2, Vaticano 1988, s. 1604n; Giovanni Paolo II, Telegrammi ai capi di stato dei paesi sorvolati, 04.05.1987, w: Insegnamenti 1987 X/2, Vaticano 1988, s. 1607; Giovanni Paolo II, Udienza generale, 06.05.1987, dz. cyt., s. 1619n; Giovanni Paolo II, Ai cardinali e ai prelati della Curia Romana ricevuti per la presentazione degli auguri natalizi, 22.12.1987, w: Insegnamenti 1987 X/3, Vaticano 1988, s. 1488; Giovanni Paolo II, Mauthausen: Incontro con alcuni superstiti nell'ex campo di concentramento, 24.06.1988, w: Insegnamenti 1988 XI/2, Vaticano 1989, s. 2145; Giovanni Paolo II, Innsbruck: Omelia della celebrazione eucaristica nel Bergisel Stadion, 27.06.1988, w: Insegnamenti 1988 XI/2, Vaticano 1989, s. 2221; Giovanni Paolo II, Paderborn: L'omelia durante la concelebrazione eucaristica sulla spianata dell'aeroporto di Sienne, 22.06.1996, w: Insegnamenti 1996 XIX/1, Vaticano 1998, s. 1554; Giovanni Paolo II, Paderborn: Il discorso nella cattedrale durante la celebrazione ecumenica della parola, 22.06.1996, w: Insegnamenti 1996 XIX/1, Vaticano 1998, s. 1569; Giovanni Paolo II, Udienza generale, 26.06.1996, w: Insegnamenti 1996 XIX/1, Vaticano 1998, s. 1619; Giovanni Paolo II, A conclusione del concerto organizzato nell'aula Paulo VI in occasione della canonizzazione di santa Teresa Benedetta della Croce, 11.10.1998, w: Insegnamenti 1998 XXI/2, Vaticano 2000, s. 722n; Giovanni Paolo II, Udienza generale, 14.10.1998, dz. cyt., s. 735; Giovanni Paolo II, Ai cardinali, alla famiglia pontificia, alla curia e alla prelatura roman adurante la presentazione degli auguri natalizi, 22.12.1998, w: Insegnamenti 1998 XXI/2, Vaticano 2000, s. 1329; Giovanni Paolo II, L'omelia per la celebrazione della solennità di Maria Santissima Madre di Dio e della XXXII Giornata Mondiale della Pace, 1.1.1999, w: Insegnamenti 1999 XXII/1, Vaticano 2002, s. 2. 


\section{Patronka Europy}

Po kanonizacji Edyty Stein najważniejszą decyzją Jana Pawła II dotyczącą jej kultu było ogłoszenie jej, wraz z innymi wielkimi kobietami Kościoła, patronką Europy w 1999 roku. Pewną zapowiedzią tej decyzji było rozważanie na Anioł Pański, w którym Edyta Stein została ukazana jako przykład ze względu na wkład w promocję kobiety. Papież przypomniał, że Edyta odgrywała wielka rolę społeczną, oddając się - na długo przedtem, zanim wstąpiła do klasztoru - inicjatywom mającym na celu przyznanie kobiecie należnych praw. Podkreślała powołanie kobiety jako oblubienicy i matki, ale też jej rolę we wszystkich obszarach życia kulturalnego i społecznego. Sama była świadkiem kobiecości społecznie aktywnej, ceniona jako badacz, myślicielka, wykładowczyni i uczestniczka licznych konferencji na temat natury i powołania kobiety ${ }^{46}$.

Ta myśl towarzyszyła papieżowi, gdy po dołączeniu świętych Cyryla i Metodego do św. Benedykta jako patronów Europy w pierwszym tysiącleciu postanowił oddać kontynent pod opiekę trzech kobiet reprezentujących drugie tysiąclecie: Brygidy Szwedzkiej, Katarzyny ze Sieny i Teresy Benedykty od Krzyża - Edyty Stein. Jan Paweł II uznał za opatrznościową tendencję w Kościele i społeczeństwie, by coraz wyraźniej uznać godność i własne dary kobiety, dlatego pragnął ukazać szczególną świętość o kobiecym obliczu. Mówiąc wprost o Edycie Stein, papież przypomniał, że nie tylko spędziła życie w różnych krajach Europy, ale swym życiem stworzyła most pomiędzy jej żydowskimi korzeniami a przynależnością do Chrystusa. Budowała mosty również w dialogu ze współczesną jej filozofią, a także jako mistyczka i męczennica. Stała się wyrazem ludzkiego, kulturowego i religijnego pielgrzymowania, które wyraża sedno tragedii i nadziei europejskiego kontynentu. Papież przypomniał jej życie i drogę duchową, w której fenomenologiczne wczucie oraz przykład mistyczek miały duże znaczenie. Szczególnie godne uwagi w tym czasie było jej waleczne działanie na rzecz społecznego awansu kobiet, co można znaleźć również w jej pismach dotyczących natury i powołania kobiety. Ostatecznie Jan Paweł II podkreślił wymiar krzyża

${ }^{46}$ Por. Giovanni Paolo II, Angelus Domini, 26.02.1995, dz. cyt., s. 434. 
przyjęty w jej męczeńskiej śmierci w solidarności z narodem żydowskim, co może stanowić wkład w budowanie europejskiego społeczeństwa braterstwa, mimo różnic etnicznych, kulturowych i religijnych ${ }^{47}$. W wielu późniejszych wystąpieniach Jan Paweł II nawiązywał do świętej Teresy Benedykty od Krzyża - współpatronki Europy ${ }^{48}$.

\section{Zakończenie}

Powyższe refleksje próbujące nakreślić związki dwojga świętych, Edyty Stein - Teresy Benedykty od Krzyża i Karola Wojtyły - Jana Pawła II, upoważniają do postawienia tezy o duchowym pokrewieństwie tych wybitnych postaci XX wieku. Podobieństwa zauważyliśmy już na poziomie

47 Por. Giovanni Paolo II, Lettera apostolica „Spes aedificandi”, 1.10.1999, w: Insegnamenti 1999 XXII/2, Vaticano 2002, s. 493-505.

48 Por. Giovanni Paolo II, L'omelia durante la solenne concelebrazione eucaristica in apertura della II assemblea speciale per l'Europa del Sinodo dei Vescovi, 1.10.1999, w: Insegnamenti 1999 XXII/2, Vaticano 2002, s. 538; Giovanni Paolo II, Parrocchia di Santa Caterina di Roma, 10.10.1999, w: Insegnamenti 1999 XXII/2, Vaticano 2002, s. 568; Giovanni Paolo II, Solenne concele brazione di chiusura della II assemblea speciale per l'Europa del sinodo dei vescovi, 23.10.1999, w: Insegnamenti 1999 XXII/2, Vaticano 2002, s. 630; Giovanni Paolo II, L'omelia durante la celebrazione ecumenica in memoria di Santa Brigida, compatrona d'Europa, 13.11.1999, w: Insegnamenti 1999 XXII/2, Vaticano 2002, s. 889; Giovanni Paolo II, Al primo gruppo dei vescovi tedeschi in visita ,ad limina”, 15.11.1999, w: Insegnamenti 1999 XXII/2, Vaticano 2002, s. 910; Giovanni Paolo II, Le credenziali del nuovo ambasciatore di Svezia, 20.12.1999, w: Insegnamenti 1999 XXII/2, Vaticano 2002, s. 1223; Giovanni Paolo II, Ai cardinali, alla famiglia pontificia, alla curia e alla prelatura roman adurante la presentazione degli auguri natalizi, 21. 12.1999, w: Insegnamenti 1999 XXII/2, Vaticano 2002, s. 1232; Giovanni Paolo II, Udienza generale, 03.05.2000, w: Insegnamenti 2000 XXIII/1, Vaticano 2002, s. 736; Giovanni Paolo II, Lettera al cardinale Edmund Casimir Szoka per la nomina a inviato speciale alle celebrazioni del millennio dell'arcidiocesi di Wrocław (Polonia), 10.06.2000, w: Insegnamenti 2000 XXIII/1, Vaticano 2002, s. 1066n; Giovanni Paolo II, L'udienza giubilare ai volontari della giornata mondiale della Gioventù e ai numerosi altri gruppi di pellegrini, 12.08.2000, w: Insegnamenti 2000 XXIII/2, Vaticano 2002, s. 158; Giovanni Paolo II, Udienza generale, 20.09.2000, w: Insegnamenti 2000 XXIII/2, Vaticano 2002, s. 425; Giovanni Paolo II, Parrocchia romana di santa Edith Stein, 20.05.2001, w: Insegnamenti 2001 XXVI/1, Vaticano 2003, s. 1033; Giovanni Paolo II, Udienza generale, 08.08.2001, w: Insegnamenti 2001 XXVI/2, Vaticano 2003, s. 147; Giovanni Paolo II, Angelus Domini, 12.08.2001, w: Insegnamenti 2001 XXVI/2, Vaticano 2003, s. 154n; Giovanni Paolo II, La celebrazione dei primi vespri per la promulgazione dell'esortazione apostolica post-sinodale „Ecclesia in Europa”, 28.06.2003, w: Insegnamenti 2003 XXVI/1, Vaticano 2005, s. 1090. 
biograficznym, na którym życiowe kryzysy, a zwłaszcza tragiczne wydarzenia drugiej wojny światowej, odcisnęły swoje piętno. Obok tych wydarzeń, o bliskości obojga świętych świadczy rozwój duchowy oparty o duchowość karmelitańską oraz ewolucja intelektualna związana z filozofią tomistyczną i fenomenologiczną. Omawianych filozofów niewątpliwie łączy przekonanie o istnieniu prawdy obiektywnej, personalizm fenomenologiczny, chęć połączenia filozofii bytu i świadomości oraz badanie doświadczenia duchowego, zwłaszcza mistycznego. Powyższe więzi usprawiedliwiają zainteresowanie Karola Wojtyły postacią Edyty Stein. Szczególnie po wyborze na Stolicę Piotrową Jan Paweł II ukazywał karmelitankę jako wierną żydowskiej tradycji konwertytkę i męczennicę, której ostatni etap życia złączył się z męczeństwem Maksymiliana Kolbego. Choć Jan Paweł II cenił dokonania naukowe Edyty Stein, o czym świadczy encyklika Fides et ratio, to głównie ukazywał ją jako znajdującą prawdę w Chrystusie męczennicę, mistyczkę krzyża, ukazującą Kościołowi znaczenie wierności, cierpienia, oraz związku prawdy z miłością, a także przykład dla współczesnych kobiet i nadzieję w dialogu chrześcijańsko-żydowskim. Jan Paweł II ukazywał te aspekty życia i działalności Edyty Stein głównie przy okazji jej beatyfikacji w 1987 roku, kanonizacji w 1998 roku i ogłoszenia jej patronką Europy w 1999 roku. 


\section{Summary}

\section{Edyta Stein - Teresa Benedykta od Krzyża w życiu w pismach Karola Wojtyły - Jana Pawła II}

Autor stara się porównać życie i twórczość Edyty Stein i Karola Wojtyły, oraz ukazać jej postać w nauczaniu Jana Pawła II. Najpierw chodzi o aspekt biograficzny. Następnie zostaje porównane podejście do badań filozoficznych. Wreszcie artykuł ukazuje nauczanie papieża na temat Edyty Stein jako filozofa, męczennicy, mistyczki i wzoru dla kobiet. Następuje to przy okazji jej beatyfikacji, kanonizacji i ogłoszenia jej patronką Europy.

Słowa kluczowe: Edyta Stein, Karol Wojtyła, filozofia chrześcijańska

\section{Edith Stein - Teresa Benedicta of the Cross in the Life and Works of Karol Wojtyła - John Paul II}

The author compares the life and the works of Edith Stein and Karol Wojtyła, and shows her in the teaching of John Paul II. The first part deals with biographical aspects. After this philosophical researches are compared. Finally the article presents the pope's teachings about Edith Stein as a philosopher, martyr, mystic and good example for women. This teaching took place on the occasion of beatification, canonization and the declaration of Edith Stein as patron of Europe.

Keywords: Edith Stein, Karol Wojtyła, Christian philosophy

\section{Bibliografia}

Giovanni Paolo II, Lettera apostolica Spes aedificandi, 1.10.1999, w: Insegnamenti 1999 XXII/2, Vaticanum 2002, s. 493-505.

Giovanni Paolo II, Lettera enciclica Fides et ratio, 14.09.1998, w: Insegnamenti 1998 XXI/2, Vaticanum 2000, s. 277-374.

Giovanni Paolo II, L'omelia durante il rito di santificazione di Teresa Benedetta della Croce (Edith Stein), 11.10.1998, w: Insegnamenti 1998 XXI/2, Vaticanum 2000, s. 713-718.

Giovanni Paolo II, Omelia durante la solenne concelebrazione nello stadio di KölnMüngersdorf, 01.05.1987, w: Insegnamenti 1987 X/2, Vaticanum 1988, s. 1485-1493.

Grzegorczyk A., Poznanie metaracjonalne Edyty Stein i Karola Wojtyły, „Kwartalnik Filozoficzny" 4 (2005), s. 61-89.

Grzegorczyk A., Wpływ myśli Edyty Stein na filozofię XXI wieku, w: Bóg i Auschwitz, red. M. Deselaers, Kraków 2007.

Kalendarium życia Karola Wojtyły, red. A. Boniecki, Kraków 2000. 
Karol Wojtyła/Jan Paweł II, Patron naszych trudnych czasów, Niepokalanów 1991.

Skrzypczak R., Edyta Stein jest perła, ,Gość Niedzielny” 32 (2017), http://gosc.pl/ doc/4093306.Edyta-Stein-jest-perla (10.08.2017).

Olejniczak M., Wolność mitości. Ontologia osoby ludzkiej w koncepcjach Edyty Stein i Karola Wojtyły, Tarnów 2010.

Półtawski A., Personalizm fenomenologiczny: Edith Stein i Karol Wojtyła, „Kwartalnik Filozoficzny" 1 (1995), s. 33-44.

Półtawski A., Realizm fenomenologii. Husserl-Ingarden-Stein-Wojtyła, Toruń 2000, s. 285.

Wojtyła K., Odezwa Ks. Metropolity w XX rocznice wyzwolenia obozu oświęcimskiego (27 I 1945 - 27 I 1964), „Notificationes e Curia Metropolitana Cracoviensi” 5 (1965), s. 112.

Zięba M., Jestem z wami. Kompendium twórczości i nauczania Karola Wojtyły - Jana Pawła II, Kraków 2010. 